\title{
The Effectiveness of Blended Learning in Enhancing Saudi Students' Competence in Paragraph Writing
}

\author{
Omar Obaid Alrouji ${ }^{1}$ \\ ${ }^{1}$ College of Sciences and Humanities, Shaqra University, Saudi Arabia \\ Correspondence: Omar Alrouji, College of Sciences and Humanities, Shaqra University, Saudi Arabia.
}

Received: July 26, 2020

Accepted: August 10, 2020

Online Published: August 18, 2020

doi: 10.5539/elt.v13n9p72

URL: https://doi.org/10.5539/elt.v13n9p72

\begin{abstract}
Blended learning approach has become an emerging trend in the field of education and has caught the attention and interest of many researchers as a new approach to encourage students in their learning process. The present study aimed at examining the effectiveness of blended learning in improving Saudi EFL students' English paragraph writing at Shaqra University. The sample of the study consists of 70 EFL students at Shaqra University. The experiment was conducted for six weeks (2018). A pre-test and post-paragraph writing test was used to measure the effectiveness of the blended learning in enhancing paragraph writing skills. Results showed that there were significant differences in the mean scores of the control group (traditional teaching mode) and the experimental group (blended learning) in favor of the experimental group. This proved the effectiveness of blended learning approach in developing Saudi students' competence in paragraph writing.
\end{abstract}

Keywords: blended learning, writing competence, paragraph writing

\section{Introduction}

\subsection{Introduce the Problem}

Writing is one of the most important communicative language skills that start from building sentences to joining them in a meaningful and communicative context. So, teaching English writing becomes one of the major concerns in any educational system around the world. It is, also, a means of communicating ideas, thoughts and emotions clearly and effectively through proper use of grammar rules (Martinez et al., 2020). Writing is a productive skill that involves three stages: pre-writing, writing, and post writing. In pre-writing stage, students collect data and outline the content. In writing stage, they do many activities for example telling a story, writing a report, a letter or a paragraph. In the post-writing stage; teachers check students' writing and give feedback on how to improve it (AlSmari, 2019). There are many kinds of writing. One of them is paragraph writing which is the basic unit of organization in writing that consists of more than two sentences. It has three main parts: a topic sentence, supporting details, and conclusion. The kinds of paragraphs that can be used are narrative, explanation, recount information, report, argumentation, and descriptive (Kartawijaya, 2018). Students may face difficulty in paragraph writing. This difficulty of writing may be due to the necessity for students to develop mastery over different sub-skills such as writing a topic sentence followed by supporting details and conclusion. These difficulties might include different teaching techniques (Karim et al., 2018). There were many changes happened in the second half of the twentieth century concerning teaching English writing: until the1970s, writing was perceived as a product, then as a process and finally as a means of social communication context in which students learn how to write in different context and for different purposes (Khwail, 2011). From the early stages to university, writing plays a vital role in the learning process. It affects students' achievement in other subjects. As they progress in their education, students work with writing skill rather than any of the other language skills. This means that they are asked to write daily and do their exams in writing, at advanced levels, they become experienced in their writing. However, writing problems become more visible and affect the learners' progress (Ghezzou \& Mammeri, 2016). Furthermore, EFL experts and researchers have paid great attention to English writing, especially paragraph writing. However, many Saudi university students have a lot of problems in paragraph writing (AlTameemy, 2019; AlSmari, 2018; Kartawijaya, 2018). Many studies have been conducted in the field of writing and concluded that writing is a difficult task for non-native learners and that Arab learners face a lot of problems in their writing especially, paragraph writing. Teachers use traditional ways in dealing with students' paragraph writing: they check each paper in isolation, and then take so long time to give their 
feedback on students' writing that they may forget all about the topic. However, in blended learning, immediate feedback is so effective that it is still fresh in students' minds. With the rapid advancement of technology and its effectiveness in teaching English, teachers tend to use technology to develop their students' writing (Al-Naibi et al., 2018). A great deal of empirical studies has been conducted to find out the effectiveness of blended learning, when the researcher reviewed literature relating to the field of blended learning and paragraph writing. This showed that little has been done to prove its effectiveness in developing students' competence in paragraph writing. Therefore, the present study became an important attempt to enhance students' competence in paragraph writing by using blended learning as a technology technique in Saudi environment. Therefore, enhancing Saudi students' competence in paragraph writing using blended learning is main concern of this study.

\subsection{Importance of the Study}

The main challenge, but also motivation for this study was the lack of research studies on the use of blended learning approach in instructing paragraph writing in the Saudi instructional settings, especially at Shaqra University. To fill in this gap, the current study aims to examine the impact of blended learning approach on improving Saudi EFL students' English paragraph writing. So, the significance of this study is threefold. At the outset, the study findings will contribute to the little literature on blended learning in Saudi EFL university settings. Second, the findings may motivate the use of technology in Saudi EFL classrooms. Finally, the results of the study can contribute to current theories that suggest blended learning approach may influence academic writing in English.

\subsection{Hypotheses of the Research}

- There are significant statistical differences in the mean score between experimental group and control group in the per-test/posttest.

- There are significant statistical differences in the posttest mean score of the experimental group in terms of writing composition components.

\section{Literature Review}

One of the major purposes of foreign language teaching is to enable students to communicate in the target language effectively and clearly. In order to achieve such a goal, language teachers implement a wide range of strategies and techniques for teaching the language skills. This means that teaching how to write in the foreign language becomes one of the most investigated issues in this regard, as follows:

\section{Blended learning}

There are many studies conducted on blended learning to prove its effectiveness in teaching environment, the researcher reviewed some of these studies in the following section: Anggrawan (2020) studied how much blended learning model contributed to students learning outcome. Findings found that models of blended learning had a great influence on students' learning success when compared to online and face-to-face classroom pattern and that mixed learning model affected learning outcome at $34.81 \%$. This meant that $65.19 \%$ of learning outcome was not affected by blended learning model. So, further studies were needed to find out what other factors influenced learning outcomes in blended learning. Similarly, AlMueezar (2020) studied the effectiveness of blended learning in developing 22 Saudi female students' research writing skills and the level of satisfaction towards this strategy. The results confirmed the effectiveness of the strategy used in developing research writing skills to a very large degree and the impact of utilizing the blended learning according to the experiment strategy contributed to increased communication and interaction and reduced pressure in the course. At the same time, Wahyudi (2020) investigated the effectiveness of sharing blended project based learning model implementation in operating system course. Findings showed that the blended model, the e-book teaching material and e-learning website were effective and that students learning motivation improved. Therefore, it was possible to apply a blended learning system in other subjects. Also, Mulyadi (2020) studied the integration of technology, pedagogy, and subject matter to enhance 70 ESP teachers' teaching quality. Findings showed that most teachers were well qualified with technology for teaching reading and speaking skills. However, they lacked technology for teaching writing skill activities and English language grammar. So, more studies were needed to use technologies in helping learners improve writing skill and enhance grammar competence. Later, $\mathrm{Yu}, \mathrm{Du}$ (2019) examined the effectiveness of a blended learning model in a content-based EFL curriculum, with a focus of collaborative and independent learning to ensure the achievement of learning outcomes. Findings proved the effectiveness of the proposed model in which students well. These findings encouraged further studies of other blended learning models for EFL learning. However, Alkubaidi (2019) investigated the challenges faced by the English language learners as they learn to write in a higher education setting. The study explained the factors 
affecting how students reflected on their practice and their decision-making power. The study revealed that the Saudi students faced difficulties in developing their English writing competence because they relied heavily on their teachers as their only source of knowledge. The study results had significantly contributed towards the understanding of Saudi students for analyzing their perceptions and expectations to make teaching practices much better in university language classrooms. The challenges are likely to be minimized by improving the language learning system, along with the quality of teaching and learning in the Saudi language classrooms. Moreover, AlQahtani (2019) studied staff members' satisfaction on teaching their blended learning courses at Bisha University. The study used a descriptive approach with a questionnaire survey. Findings revealed that 56 staff members have high level of satisfaction on teaching their blended learning courses in general and there was no statistical difference in the mean score of staff members' high level of satisfaction on teaching their blended learning courses in general and the scientific rank, sex, experience in teaching. And, Khaireddeen (2019) studied the degree of using the blended learning methods by teachers of Arabic teachers and their attitudes towards them and differences in it according to the variables of the academic stage, the academic qualification and the years of experience. Results showed that there were statistically significant differences in the degree of using blended learning method due to the variable of the secondary school stage and the qualification variable in favor of the postgraduate studies, while there were no statistical differences due to the variable of years of experience. These studies proved the effectiveness of blended learning as a teaching mode for developing writing skills and this paves the way to the present study to use blended learning as its main concern.

\section{Paragraph writing}

Writing is an important skill for learners through which they convey their ideas and thoughts clearly. The main part of a writing composition is paragraph. A paragraph is a group of related sentences dealing with a topic sentence that introduces the main idea of the whole paragraph, and then supporting details give more examples and explanations to the main idea, ending the paragraph with a conclusion that summarizes the whole idea of the paragraph (Aldera, 2016). Moreover, the proper organization of thoughts in writing leads from one sentence to another and from one paragraph to the next logically and coherently. This means that a paragraph is a skill in which a number of sentences can be arranged in a particular order and joined together in certain ways. Hence, English language students are carefully taught these mechanics of writing right from elementary to advanced level (Aldera, 2016). So, a brief survey of researches was done in this area to justify the feasibility and validity of the present study: Haerazi et al. (2020) investigated the effectiveness of the mobile-assisted language learning towards pre-service teachers' writing skills in relation to critical thinking ability. The study was a mixed method (qualitative and quantitative). Qualitative data were collected using observation sheets and qualitative data were collected from experimental design through a nonequivalent control-design. Findings showed that the use of mobile-assisted language learning model was more effective than non-mobile learning to improve 58 pre-service teachers' writing skills in relation to critical thinking skills. Similarly, Sabarun (2019) investigated the learning needs of 20 students in paragraph writing. Findings showed that students' difficulty in paragraph writing was grammar and that they preferred to get help from internet than from other sources. That is, internet-based materials were preferred for developing EFL paragraph writing. At the same time, AlSmari (2019) investigated the effect of using Edmodo, a web2.0 tool, as a supportive blended learning tool in developing 80 EFL Saudi students' paragraph writing skills. Findings showed that using Edmodo in teaching paragraph writing was highly effective in developing EFL students' writing and that using Edmodo also enriched students' knowledge and increased their motivation to learn. Moreover, AlTameemy (2019) analyzed the types and frequencies of errors in paragraph writing made by 80 EFL Saudi students at Prince Sattam bin Abdul-Aziz University. After analyzing 80 paragraphs at the sentence-level and the paragraph-level using a particular rubric, findings showed that the common paragraph writing errors were in grammar, punctuation, spelling and capitalization. In addition, there were errors in paragraph development, paragraph coherence, paragraph unity and inconsistency of point of view. Also, Kartawijaya (2018) studied improving students' writing skill in writing paragraph through an online technique and some factors that influenced the students in writing descriptive paragraph. Findings showed that teaching writing through online improved students' writing skill especially in writing descriptive paragraph. And that students' writing were influenced by several factors, namely, material given, media, teaching technique, and classroom management. Finally, Al-Naibi (2018) measured the effectiveness of integrating a social networking website "Edmodo" in students' paragraph writing in EFL classroom. Findings showed that analysis of 25 students' paragraph writing indicated a statistically significant improvement in students' paragraph structure and sentence structure and that they had positive perceptions towards using Edmodo in language learning. 


\section{Commentary}

From the above brief literature review, it can be concluded that most of the researches have concentrated on the effectiveness of blended learning in general (Anggrawan, 2020; AlMueezar, 2020; Wahyudi, 2020; Mulyadi, 2020; Haerazi et al., 2020). Hence, the present study agrees with the aforementioned studies in that it deals with the blended learning and writing skill. However, it is different from the preceding ones in the following: it enhances Saudi students' competence in paragraph writing using blended learning in Shaqra University. Moreover, the sample of the study consists of seventy students representing the Saudi environment and that is different from the sample of the previous studies that is completely different in its nature, culture, and ability. However, none of them has examined its effectiveness in enhancing Saudi students' competence in paragraph writing. Therefore, the present research fills in this gap and is concerned with such investigation. It focuses more on blended learning to develop Saudi students' competence in paragraph writing in Saudi teaching environment.

\section{Methodology}

\subsection{Participants Characteristics}

The participants' age ranges between 19-20 years old. They were enrolled in the Writing Course (1). The study sample was equally divided into two separate classes. The first class included thirty five students and it was called the control group and was subjected to the conventional paragraph writing teaching and learning approach. The second class included thirty five students and was called the experimental group and was subjected to the blending learning approach. Both groups were taught by the same teacher and received paragraph writing instruction for two hours weekly for fifteen weeks. While experimental group students had access to personal computers, students of the control group were not allowed to use any type of technology in their paragraph writing during the study. Students were informed about this research study and they signed a consent form to participate in it. They were also informed that they could withdraw from this research study whenever they wanted to without penalty. The study participants were ensured that their information was considered confidential and they were told that this study was conducted for research purposes and to improve paragraph writing instruction at Shaqra University.

\subsection{Sampling Procedures}

\subsubsection{Recruitment}

The selection of the control and experimental groups was based on random selection. The study was conducted in September 2019 and lasted for fifteen weeks. Every week at the end of the lesson, the lecturer would select the specific topics for students to write on. Each student wrote with the certain criteria and posted them online. The teacher and students provided comments on posts related to paragraph writing and all students were encouraged to give feedback on posted writing. The period between pre-test and post-test was fifteen weeks to reduce any possible effect of pre-test on students' responses in post-test.

\subsubsection{Sample Size}

The sample of the present study consisted of seventy Saudi undergraduate students studying in the first year in the English language department at Shaqra University, Saudi Arabia.

\subsection{Measures and Covariates}

- A paragraph writing pre-test was administered to the two study groups on 4th, September 2019 to assure equality of the control experimental group students' writing ability.

- At the end of the experiment on 14th, December 2019, the researcher administered the writing post-test to both groups.

\subsection{Research Design}

The current research was undertaken to explore the effects of using blended learning on English paragraph writing skills of Saudi EFL students. It was conducted at Shaqra University, Saudi Arabia from the 4th, September 2019 to the 14th, December 2019. A quantitative research methodology was deemed appropriate for collecting the required data for this research. Within the quantitative approach, an experimental design was used. The experimental design was, therefore, deemed compatible with the primary goal of the present study, which intended to investigate the impact of blended learning approach on students' paragraph writing of Shaqra University. The experimental group was taught writing using blended learning approach, whereas, the control group was taught using the conventional teaching mode. The independent variable was the mode of instruction, which included the blended learning in the experimental EFL writing class and the conventional paragraph writing in the control group. The dependent variable was students' competence in paragraph writing. 


\subsection{Data Analysis}

SPSS (Statistical Package for the Social Science, version 17) was used to analyze the data obtained from participants' paragraph writing to determine if there were any significant statistical differences in students' competence after implementing the treatment. A paired sample t-test was carried out to compare the mean difference between pre- and post-test scores of each group. An independent sample t-test was also used to obtain the mean difference between the two groups' pre- and post-test scores. In this study, the significance level of $\mathrm{p}$-value $<.05$ was used. The data obtained from the paragraph writings of the participants were also used to answer the second question of the study which dealt with the effect of the blended learning on the students' writing competence.

\subsection{Reliability of the Paragraph Writing Test}

Reliability denotes the ability of the scale to produce consistent results when completed under similar conditions. It is analogous to the scale's precision. (Agala et al., 2020). This means that if the students take the test twice, both students' results and the relationship among their results should be similar across the tests. In the current study, the researcher made sure that there was an overall consistency of the conditions in which the pre-test and posttests are administered. To ensure reliability of scoring students' writing products, three college English instructors have worked together to grade each students writing product. The final score for each student' writing product was recorded as the average of three instructors' scoring (Zhou, C., 2018).

\subsection{Validity of the Paragraph Writing Test}

Validity denotes the extent to which a scale measures the construct it is supposed to. It is analogous to the scale's accuracy. (Agala et al., 2020). This means that there is a connection between the purposes of the research and its data collection to achieve these purposes. Therefore, the researcher offered the paragraph writing competence test to jury members for proving their validity (i.e., they measure what they are supposed to). Modifications will be made according to their direction and guidance.

\subsection{Experiment Manipulations or Interventions}

The experimental group was taught using blended learning. In contrast, the control group was taught using the traditional method (board, pen and paper). Both experimental and control groups were taught paragraph English writing by the same teacher. Before the beginning of the treatment, both groups underwent a pre-test to determine, if they had the same level of proficiency. The pre-test of both groups was conducted on the same day. Then, the experiment was carried out for fifteen weeks by two sessions a week for both the experimental group and the control group. Both groups received thirty teaching sessions in fifteen weeks. Participants of both experimental and control groups were asked to write fifteen paragraphs in fifteen week experiment and submitted them to the teacher to obtain feedback. The experimental group wrote their paragraphs on their accounts; they were also asked to comment on their classmates' posts. The teacher checked students' posts and the feedback. The instruction was conducted in the classroom using the traditional method of teaching (board, paper, and pen), while the instruction of the experimental group was done in the computer lab using blended learning. After conducting the experiment for fifteen weeks, the post-test was administered to both groups on the same day. After collecting the paragraphs from the participants, two raters assessed the pre- and post-tests by using a scoring rubric designed by the researcher (Appendix: 1).

\section{Results}

\subsection{Statistics and Data Analysis}

Analysis of the pre-and post-tests of the control and experimental groups including the overall results of both groups as well as the writing components, namely, organization, content, vocabulary, language use, and mechanics. Then, the results of both groups on the post-tests overall and in terms of the writing components will follow. Third, a comparison of the mean scores on the pre- and post-tests within each group is presented. Finally, a comparison of the mean scores on the pre-and post-tests of both the control and experimental groups overall and in terms of each writing component will be presented.

\section{Pre-test Results of the Experimental and Control Groups}

The pre-test of both experimental and control groups was administered on the same day. The goal was to assess the level of paragraph writing skill of the students before conducting the experiment and to test whether there is any statistically significant (Sig.) difference at $p<.05$ level between the mean gain scores of the two groups. An independent sample t-test was used (see Table 1). 
Table 1. The mean (M) performance and standard deviation (SD) of the pre-test of the control and experimental groups

\begin{tabular}{|c|c|c|c|c|c|}
\hline Components & Group & $\mathbf{M}$ & SD & t-test & Sig. \\
\hline \multirow{2}{*}{ Organization } & Control & 4.00 & .874 & & \\
\hline & Experimental & 4.54 & 1.010 & -.2404 & .128 \\
\hline \multirow{2}{*}{ Content } & Control & 3.97 & 1.248 & & \\
\hline & Experimental & 3.51 & 1.147 & -1.595 & .643 \\
\hline \multirow{2}{*}{ Vocabulary } & Control & 3.63 & 1.395 & & \\
\hline & Experimental & 3.69 & 1.295 & -.180 & .392 \\
\hline \multirow{2}{*}{ Language use } & Control & 4.31 & 1.231 & & . \\
\hline & Experimental & 4.80 & 1.368 & -.1561 & .730 \\
\hline \multirow{2}{*}{ Mechanics } & Control & 2.94 & 1.413 & & \\
\hline & Experimental & 2.43 & 1.420 & -1.519 & .757 \\
\hline \multirow{2}{*}{ Overall } & Control & 18.31 & 3.660 & & \\
\hline & Experimental & 18.53 & 3.788 & -.241 & 699 \\
\hline
\end{tabular}

Table 1 shows although there are slight differences in the mean scores between control and experimental groups in terms of each writing category, there is no significant difference between the experimental group and the control group before the intervention in terms of organization, content, vocabulary, language use, and mechanics. Overall, the findings showed that the mean score of the control group was 18.31 with a standard deviation of 3.66 , and the mean of the experimental group was 18.53 with a standard deviation of 3.78 . Thus, it can be implied that the participants of both groups (experimental and control) were approximately at the same level of writing performance before the experiment.

\section{Post-test Results of the Control and Experimental Groups}

An independent-samples t-test was used to test whether there is any statistically significant difference at $\mathrm{p}<.05$ level between the post-test mean gain scores of the experimental and control groups.

Table 2. The mean (M) performance and standard deviation (SD) of the post-test of control and the experimental groups

\begin{tabular}{|c|c|c|c|c|c|}
\hline Components & Group & $\mathbf{M}$ & SD & t-test & Sig. \\
\hline \multirow{2}{*}{ Organization } & Control & 4.54 & .950 & & \\
\hline & Experimental & 7.71 & .957 & -13.913 & .911 \\
\hline \multirow{2}{*}{ Content } & Control & 4.11 & 1.586 & & \\
\hline & Experimental & 5.51 & 2.063 & -3.182 & .034 \\
\hline \multirow{2}{*}{ Vocabulary } & Control & 4.43 & 1.650 & & \\
\hline & Experimental & 6.03 & 2.051 & -3.596 & .074 \\
\hline \multirow{2}{*}{ Language use } & Control & 4.74 & .950 & & \\
\hline & Experimental & 7.89 & .993 & -13.528 & .622 \\
\hline \multirow{2}{*}{ Mechanics } & Control & 2.43 & 1.632 & & \\
\hline & Experimental & 3.77 & 1.629 & -3.446 & .829 \\
\hline \multirow{2}{*}{ Overall } & Control & 20.73 & 4.551 & & \\
\hline & Experimental & 30.86 & 5.801 & -8.413 & .000 \\
\hline
\end{tabular}

Table 2 shows that the post-tests mean scores of the experimental group on each writing component are higher than their counterparts in the control group. For example, the students' organization post-test mean score in the experimental group is $(M=7.71)$, which is higher than that of the control group $(M=4.54)$. However, the result of an independent t-test showed different statistical significance. Even though organization, language use, and mechanics showed no statistically significant, content showed a significant $(\mathrm{p}<0.05)$ result and vocabulary was marginally significant at $p=.074$. Moreover, the overall scores of the post-test in both groups show statistically significance at $\mathrm{p}<0.05$. 


\subsection{Ancillary Analysis}

Comparison of the Mean Scores between Pre-and Post-test of Control and Experimental Groups

A paired t-test was conducted to show whether there is any statistically significant difference at $p<.05$ level between the pre- and post-test of each group. Table 3 shows the overall mean scores (M), standard deviation (SD), degree of freedom (DF), and significance of pre- and post-test of the total number (N) of each group.

Table 3. Mean (M) and standard deviation (SD) of pre- and post-tests of control and experimental groups

\begin{tabular}{llllllll}
\hline Group & Test & N & M & SD & df & t-test & Sig. \\
\hline \multirow{2}{*}{ Control } & Pre-test & 35 & 18.31 & 3.660 & & & \\
& Post-test & 35 & 20.37 & 4.551 & 34 & -4.071 & .000 \\
\multirow{2}{*}{ Experimental } & Pre-test & 35 & 18.53 & 3.788 & & & \\
& Post-test & 35 & 30.86 & 5.801 & 34 & -20.094 & .000 \\
\hline
\end{tabular}

Table 3 shows that students in both groups did significantly better on their post-tests. The results show a statistically significance difference between pre- and post-test of each group with a $p$ value $<.05$. It also shows, as discussed in Table 1, no significant difference between the mean scores of the overall writing performance on the pre-test of the control group $(\mathrm{M}=18.31)$ and experimental group $(\mathrm{M}=18.53)$. However, the mean scores on the post-test of control group ( $\mathrm{M}=20.37)$ and of experimental group $(\mathrm{M}=30.86)$ show a significant difference.

Comparison of the Pre- and Post-test Mean Scores of the Experimental Group in Terms of Writing Components

Table 4 below shows the pre- and post-test results of the experimental group. A paired-t test was conducted to show whether there is any statistically significant difference at $\mathrm{p}<.05$ level between the pre- and post-test of each writing component of the experimental group.

Table 4. Pre- and post-test mean scores of aspects of writing performance of the experimental group

\begin{tabular}{|c|c|c|c|c|c|c|c|}
\hline Components & Test & $\mathbf{N}$ & M & SD & df & t-test & Sig. \\
\hline \multirow{2}{*}{ Organization } & Pre-test & 35 & 4.54 & 1.010 & & & \\
\hline & Post-test & 35 & 7.71 & .957 & 34 & -14.246 & .000 \\
\hline \multirow{2}{*}{ Content } & Pre-test & 35 & 3.51 & 1.147 & & & \\
\hline & Post-test & 35 & 5.51 & 2.063 & 34 & -5.873 & .061 \\
\hline \multirow{2}{*}{ Vocabulary } & Pre-test & 35 & 3.69 & 1.255 & & & \\
\hline & Post-test & 35 & 6.03 & 2.051 & 34 & -7.710 & .002 \\
\hline \multirow{2}{*}{ Language use } & Pre-test & 35 & 4.80 & 1.368 & & & \\
\hline & Post-test & 35 & 7.89 & .993 & 34 & -9.768 & .000 \\
\hline \multirow{2}{*}{ Mechanics } & Pre-test & 35 & 2.34 & 1.420 & & & \\
\hline & Post-test & 35 & 3.77 & 1.629 & 34 & -4.379 & .082 \\
\hline
\end{tabular}

Table 4 shows that the mean scores of writing components of post-tests are higher than those of the pre-tests. For example, the mean score of language use on the post-test $(M=7.89)$ is higher than that on the pre-test $(M=4.80)$. As can be seen in Table 4, except for mechanics, there was a statistically significant difference in almost all the other language components.

\subsection{Participant Flow}

For the purpose of this study pre-test and post-test paragraph writing was designed based on the researcher's experience in teaching English writing. The paragraph writing test was administered to participants before and after the treatment. It should be noted that the tests had some topics that are similar to the topics of TOEFL but related to Saudi culture, nature and environment.

\section{Discussion}

Results of the study proved the effectiveness of using blended learning as an approach to teach paragraph writing. As can be seen in Table 1, students in both the control and the experimental groups did not show any major score differences in terms of each writing component (i.e., organization, content, vocabulary, language use, and mechanics), or their overall writing performance. After fifteen weeks of instruction, both groups' overall writing performance improved as shown in Table 3. However, the difference of mean scores of pre-tests $(M=18.31)$ and 
post-tests $(M=20.37)$ of the control group is not high. On the other hand, the difference of mean scores of pre-tests $(M=18.53)$ and post-tests $(M=30.86)$ of the experimental group is significantly high. Looking at Table 4 , it is clear that the mean scores of experimental groups on the post-test are greater than those on the pre-tests. However, statistically speaking, it seems blended learning has a more positive impact on students' content, organization, vocabulary, and language use, and less effective on students' improvement of mechanics. Hence, the use of a blended mode of instruction compared to traditional in-class writing instruction seems to be effective on improving Saudi EFL learners' paragraph writing performance. This finding is in line with previous studies (e.g. AlSmari, 2019; AlTameemy, 2019; and AlNaibi, 2019). In this study, the blended mode of instruction enhanced EFL students' writing ability and resulted in improvement in every writing component of the rating scale on the post-test. In essence, the experimental group that used blended learning obtained higher scores compared to the control group that used traditional instruction. Also, using blended learning seems to be effective in improving students' writing and help them perform better using authentic language interaction compared to traditional method. This result is consistent with previous research (e.g., Wahyudi, 2020; Khaireddeen, 2019). Indeed, Zhou (2019) emphasized that authentic language interaction through blended learning can improve their English language skills, including paragraph writing. Similarly, this finding is in line with the results of Mulyadi et al. (2020) which showed the online communication of the experimental students increased when the course content and authentic materials were uploaded online. This may explain the reason why the experimental group's results in the post-tests were significantly better than the pre-test results. This improvement in the performance of the experimental group in paragraph writing can, moreover, be attributed to the fact that students were more motivated to learn when they are offered a learning opportunity in different ways such as the use of online technology (Anggrawan, 2020). Another possible explanation of the improvement is the teacher's use of more writing exercises as all the online tasks were additional to the tasks already used in the traditional classroom instruction. In fact, Ahmed (2020) found that online tasks and use of additional online exercises resulted in significant improvement in students' overall writing performance. To sum up, the blended learning mode of instruction seemed to present an easy and interesting way of improving paragraph writing for Saudi students. Blended learning does not require students' high technical and computer skills. Thus, the students who have the least experience of dealing with the new technology get maximum benefits of the blended learning approach. Also, the direct feedback given to students could have helped students to be motivated irrespective of their general level of English proficiency or their writing level. Therefore, the improvements in the scores show that appropriate blending of online and offline resources and face-to-face sessions were effective in developing Saudi university students' paragraph writing competence. Findings of the present study are in line with previous ones conducted on blended learning and writing skills of Saudi students (e.g., Alkubaidi, 2019) and of EFL students (e.g., Martinez et al., 2020). These studies high effects of blended learning on EFL students' paragraph writing competence.

\section{Conclusion}

A summary of the study results included pedagogical implications of the study, limitations of the study and suggestions for further studies.

\section{The Summary of Results}

The present study investigated the use of blended learning in paragraph writing at Shaqra University, Saudi Arabia in terms of organization, content, language use, grammar, and mechanics. The results suggested that online learning approaches including blended learning play a vital role in teaching writing. The study results are in line with previous research on the positive impact of blended learning on EFL students' writing. Indeed, blended learning leads the students to move towards a more independent practice towards English writing rather than considering direct instruction. That is, teaching writing can be meaningful and student-centered through an online learning environment. Admittedly, the students in experimental group show better results in terms of the writing components than their peers in the control group. Overall, it can be said the differences in the students' post-test scores, which are in favor of the experimental group, are due to the use of blended learning environment in which students receive access to online materials using their personal computer. In such an environment, student may feel confident and encouraged to practice and improve their writing. Therefore, the success of the blended learning as an innovative tool for developing paragraph writing can be ascribed to two main factors. The first factor is the learning atmosphere presented in the present study. This learning atmosphere makes students more confident; the results may explain that the participants are motivated to correct their own mistakes as well as the mistakes of their classmates. Furthermore, they felt free in their practicing and learning of writing. The second factor lies in the combination of online learning activities with traditional learning activities 
of EFL writing. This combination provides learners with more flexibility in the learning setting in such a way as to accommodate for individual differences among students in learning habit and styles.

\section{Pedagogical Implications}

Based on the results of the study, the following implications can be drawn:

1. The blended learning approach can be useful in the teaching of English skills in general, and of paragraph writing in particular.

2. The blended learning approach can be a good means for helping shy learners to participate in online technology by interacting with peers and teachers through online discussion boards.

3. The blended learning approach can help students in the learning process as it facilitates communication, interaction, and direct feedback.

4. Teaching programs can be computerized and taught via the blended learning approach to help learners develop an efficient composing process that enhances the development and competence of the writing skill.

5. Teachers should be familiar with their students' individual differences and needs.

The following are indeed required to design and implement a blended mode of instruction.

1. Teacher should be trained to teach writing via blended approach at schools and universities.

2. Teachers should be preoccupied with the development and competence of writing rather than keep hunting for tiny mistakes.

3. Universities should incorporate the blended learning approach in their courses in general and in their paragraph writing courses in particular.

4. Universities should train both teachers and students so that they can use the Internet in their courses in general and in their paragraph writing courses in particular.

5. Training teachers on the strategies, types and implementation of the blended learning approach should be a pre-requisite for university students.

\section{Limitations of the Study}

The study was conducted in fifteen weeks. Future research should consider a longer study period of more than one semester, in order to allow more exposure to writing skills using blended learning. Another limitation is related to gender. The study subjects are all male students due to the nature of the context of Saudi Arabia. Finally, this study used only a quantitative research method of quasi experimental. Future study using a mixed method approach is needed. In particular, a mixed method design is called for to assess the impact of this blended learning mode on writing English and the students' and teachers' perspectives on the use of blended learning.

\section{Suggestions for Further Studies}

Based on the findings of the current study, the process of teacher preparation should take blended learning Such as computers and internet technology in future training programs.

Similar quantitative and qualitative studies should be conducted to investigate the effectiveness of blended learning in improving other language skills.

It is also recommended that using blended learning should be extended to students in other levels and to other EFL courses and skills taught at campus such as speaking, listening, reading, spelling, grammar, and vocabulary building.

In the end, similar wide-scale studies should be performed to investigate the effect of blended learning English language skills other than academic writing skills using effective practices and intensive training especially.

Similar wide-scale studies should be conducted on the effect of blended learning on English language skills in pre-university educational stages.

\section{Acknowledgement}

I would like to give my deep thanks to my college members at Shaqra University for their unlimited help and support to me all the time in need. 


\section{References}

Agala, C. et al. (2020). Reliability, Validity and Measurement Invariance of the Simplified Medication Adherence Questionnaire (SMAQ) Among HIV Positive Women in Ethiopia: A Quasi-Experimental Study. BMC Public Health. http://doi.org/10.1186/S12889-020-08585-w

Aggrawan, A. (2020). Percentage of Effect of Blended Learning Model on Learning Outcome, Consortium-Saudi Arabia SDL, IEEE Xplore.

Ahmed, Z. (2020). Action Research In EFL: Exploring Writing Pedagogy through a Task-Based Lesson Delivery. Journal of Language Teaching and Research, 11(3), 379-388. https://doi.org/10.17507/jltr.1103.06

Aldera, A. (2016). Cohesion In Written Discourse: A Case Study of Arab EFL Students. Arab World English Journal (AWEJ), 7(2), 328-341. https://doi.org/10.24093/awej/vol7no2.22

Alkubaidi, M. (2019). An Action Research on EFL Writing Dilemmas: A Case of Saudi Students and Instructors. Arab World English Journal, 10(3). https://doi.org/10.24093/awej/vol10no3.10

Al-Mossawi, O. (2017). Communicative Competence. Department Of English, University Of Al-Qadissiya College Of Education, Ministry Of High Education and Scientific Research.

Al-Naibi, I. et al. (2018). Promoting Students' Paragraph Writing Using Edmodo: An Action Research. TOJET: The Turkish Online Journal Of Educational Technology, 17(1).

AlQahtani, M. (2019). Staff Members' Satisfaction On Teaching Their Blended Learning Courses At Bisha University. Drasat. Educational Sciences, 46(1).

AlSmari, N. (2019). Fostering EFL Students' Paragraph Writing Using Edmodo. English Language Teaching, 12(10). https://doi.org/10.5539/elt.v12n10p44

AlTameemy, F. (2019). Common Paragraph Writing Errors Made By Saudi EFL Students' Error Analysis. Theory And Practice In Language Studies, 9(2). 178-187. https://doi.org/10.17507/tpls.0902.07

Ghezzou, N., \& Mammeri, S. (2016). Investigating Intralingual And Interlingual Errors Of Algerian Middle School EFL Learners In Their Written Compositions, A Case Study. The Buckingham Journal Of Language And Linguistics, 9, 58-74.

Karim, S. et al. (2018). Writing Strategy Instruction to Improve Writing Performance of Bangladeshi EFL Learners: A Case Study. Journal of Social Sciences and Humanities, 15(4). 126-136.

Kartawijaya, S. (2018). Improving Students' Writing Skill In Writing Paragraph Through An Online Technique. Curricula Journal Of Teaching And Learning, 3(3). https://doi.org/10.22216/jcc.2018.v3i3.3429

Khaireddeen, L. (2019). The Degree Of Using Blended Learning Between Arabic Teachers And Their Attitudes Towards It In Najran Region. Drasat. Social Studies And Humanities, 2(14).

Khwailch, F. (2011). The Effect Of Wh-Questions On The Quantity And Quality Of Low-Level Achieving Students' Paragraph Writing At The University Level. Drasat. Educational Sciences, 38(1).

Martinez, J. et al. (2020). Using Process Writing In The Teaching Of English As A Foreign Language, Revista Caribena De Investihacion Educative, 4(1), 49-61. https://oi.org/10.32541/recie.2020.v41il.pp49-61

Mulyadi, D. et al. (2020). Technological Pedagogical and Content Knowledge of ESP Teachers in Blended Learning Format. International Journal of Emerging Technologies in Learning, 15(6). https://doi.org/10.3991/ijet.v15i06.11490

Wahyudi, W. (2020). The Effectiveness of Sharing Blended Learning Project Based Learning (SBPBL) Model Implementation in Operating System Course. International Journal of Emerging Technologies in Learning, 15(5). https://doi.org/10.3991/ijet.v15i05.11266

$\mathrm{Yu}, \mathrm{W} .$, \& Du, X. (2019). Implementation of Blended Learning Model in Content-Based EFL Curriculum. IJET, 14(5). https://doi.org/10.3991/ijet.v14i05.8546

Zhou, C. (2018). Empirical Study On The Effectiveness Of Teaching Model Of College English Writing Within Blended Learning Mode. Educational Sciences: Theory And Practice, 18(5), 1060-1076. http://dx.doi.org/10.12738/estp.2018.5.009 


\section{Appendix 1}

\section{A Sample of Student's writing}

Shagra University
College of Education
English Department
Subject: Writing 2
Date/ $10 / 4 / 1440$

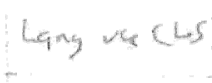

\begin{tabular}{|c|c|}
\hline argan-(arg) & 6 \\
\hline conknt (con) & 4 \\
\hline Vocab- $(v a)$ & 4 \\
\hline Mechario (M) & 5 \\
\hline
\end{tabular}

Do vou agree or disagree with the following statement? "Universities should give the same amount of money to their students' sports activities as they give to their university libraries. Use specific reasons and examples to support your opinion."?

$$
60
$$

All the cunversities apound theroth offer their students

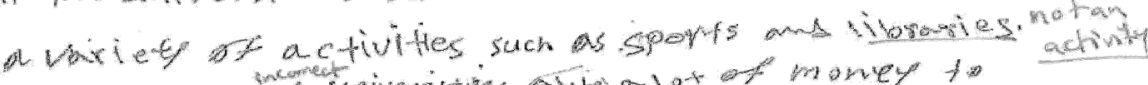

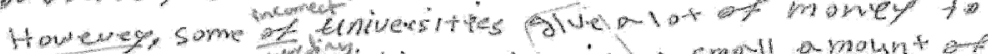

ikonaries's wetivities and gave om smoll amount ont money to others onctivities. We wexpersins rwhas may

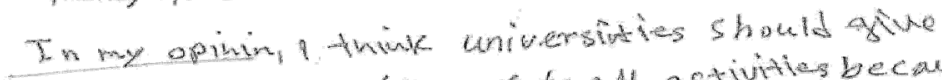

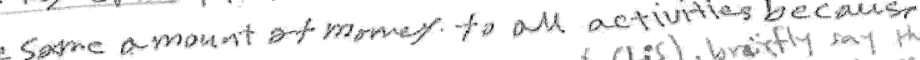

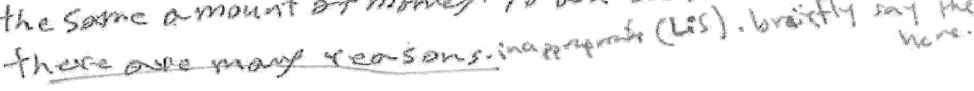

The first reason sall universitues hime to tow

jos The second repson is a pont studewts. there are alot of studeots who dont ike onctivities which we orelated to librarios pand ving prefor

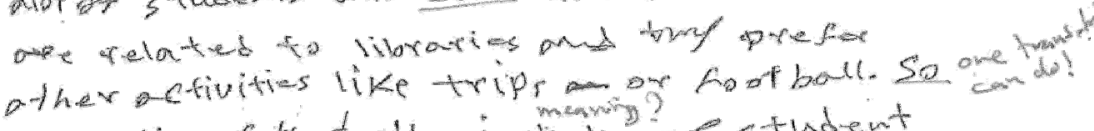
as result of thot the in take af stwdent in the octivitas will de creose.

Conclusin?

\section{Copyrights}

Copyright for this article is retained by the author(s), with first publication rights granted to the journal.

This is an open-access article distributed under the terms and conditions of the Creative Commons Attribution license (http://creativecommons.org/licenses/by/4.0/). 